\title{
Horseradish peroxidase encapsulation in alginate microspheres in the presence of imidazolium ionic liquids
}

\author{
Flávia Michelle Santos ${ }^{1}$, Raiane Maiara dos Santos²* Micael Melo², Heiddy Alvarez ${ }^{2}$, Álvaro Lima', \\ Cleide Mara Soares ${ }^{1}$, Alini Fricks ${ }^{1}$ \\ From 5th Congress of the Brazilian Biotechnology Society (SBBIOTEC) \\ Florianópolis, Brazil. 10-14 November 2013
}

Biocatalysis with free enzymes may not be economically viable due to the complexity of their recovery in the reaction medium. With the objective of enabling the total activity recovery yield of biocatalyst and to improve the operational characteristics, have been applied enzyme immobilization techniques. The main interest in the enzyme immobilization is to obtain a catalyst whose activity and stability is not affected during the process when compared to the free enzyme. The objective of this work was to immobilize horseradish peroxidase (HRP) by encapsulation method in alginate microspheres in the presence of imidazolium ionic liquid (ILs). The enzyme encapsulation was carried with the enzyme incorporation in an aqueous solution of sodium alginate to $0.05 \%(\mathrm{w} / \mathrm{v})$. The influence of the enzyme loading was studied in the range of 0.0406-0.65 mg HRP / g alginate. Alginate microspheres were obtained by dripping in calcium chloride solution (1M) according to literature [1]. The HRP immobilization in the presence of ILs was conducted using the enzyme loading more appropriate, incorporating in the immobilization medium $1 \%(\mathrm{w} / \mathrm{v})$ of IL. The ILs studied as additives were: $\left[\mathrm{C}_{4} \mathrm{mim}\right] \mathrm{TF}_{2} \mathrm{~N} ; \quad\left[\mathrm{C}_{4} \mathrm{mim}\right] \mathrm{BF}_{4} ; \quad\left[\mathrm{C}_{4} \mathrm{mim}\right] \mathrm{HSO}_{4}$; $\left[\mathrm{C}_{4} \mathrm{mim}\right] \mathrm{Ac}$ e $\left[\mathrm{C}_{4} \mathrm{mim}\right] \mathrm{PF}_{6}$. The activity of free and immobilized enzyme was verified by colorimetric method based on the change of absorbance at $470 \mathrm{~nm}$ due to the formation of product in guaiacol oxidation for three minutes. The results obtained for biocatalysts immobilized by encapsulation suggest that the use of IL as an additive in the immobilization process causes a significant increase in the total activity recovery yield (RA) HRP (increase from 5.2 to $23.5 \%$ ). The results for the HRP immobilization showed that RA was $23.5 \%$ and $20.40 \%$ for the LIs $\left[\mathrm{C}_{4} \mathrm{mim}\right] \mathrm{HSO}_{4}$ and $\left[\mathrm{C}_{4} \mathrm{mim}\right] \mathrm{TF}_{2} \mathrm{~N}$, respectively. [C4mim] Ac provided RA of $13.3 \%$, while the biocatalyst with [C4mim] $\mathrm{PF}_{6}$ showed RA of $17.3 \%$. The [C4mim] $\mathrm{BF}_{4}$ showed the lowest performance as an additive among the ILs studied. According to Diego et al.(2009) [2] there is not have a rule to predict the behavior of immobilized enzymes in the presence of ILs. The results obtained for biocatalysts immobilized by encapsulation in alginate microspheres show that the use of ionic liquids in this process had a positive effect on the activity of the immobilized biocatalyst. Additional studies in the structural characteristic of the immobilized biocatalyst are being conducted to evaluate the influence of ILs in the supporting structure.

\section{Authors' details}

'Universidade Tiradentes, Instituto de Tecnologia e Pesquisa, Aracaju, SE, Brasil. ${ }^{2}$ Universidade Tiradentes, Aracaju, SE, Brasil. ${ }^{3}$ Universidade Estadual de Feira de Santana, Departamento de Ciências Exatas, Feira de Santana, BA, Brasil.

Published: 1 October 2014

\section{References}

1. Matto M, Husain Q: Calcium alginate-starch hybrid support for both surface immobilization and entrapment of bitter gourd (Momordica charantia) peroxidase. Journal of Molecular Catalysis B: Enzymatic 2009, 57:164-170.

2. Diego T, Lozano P, Abad MA, Steffansky K, Vaultierb M, Iborra JL: On the nature of ionic liquids and their effects on lipases that catalyze ester synthesis. Journal of Biotechnology 2009, 140:234-241.

doi:10.1186/1753-6561-8-S4-P191

Cite this article as: Santos et al:: Horseradish peroxidase encapsulation in alginate microspheres in the presence of imidazolium ionic liquids. BMC Proceedings 2014 8(Suppl 4):P191.

2Universidade Tiradentes, Aracaju, SE, Brasil

Full list of author information is available at the end of the article 